\title{
NGOs' Advertising in South Africa and Implications for NGOs in China
}

\author{
Sijia Liu ${ }^{1}$, Vivian G. Kirby ${ }^{2} \&$ Paul D. Berger ${ }^{1}$ \\ ${ }^{1}$ Bentley University, Waltham, MA, U.S.A \\ ${ }^{2}$ Kennesaw State University, Atlanta, GA., U.S.A. \\ Correspondence: Paul D. Berger, Marketing Department, Bentley University, Waltham, MA, U.S.A. Tel: \\ 1-617-974-5888. E-mail: pberger@bentley.edu
}

Received: November 19, 2016 Accepted: December 10, 2016 Online Published: January 16, 2017

doi:10.5539/ijms.v9n1p18 URL: http://dx.doi.org/10.5539/ijms.v9n1p18

\begin{abstract}
In this paper, we discuss NGOs (Non-Governmental Organizations) and NPOs (Non-Profit Organizations) in general and focus on the advertising strategy NGOs should undertake. More specifically, we compare and contrast the NGO history in South Africa and China, its corresponding past advertising, and implications for advertising strategy for Chinese NGOs going forward. This includes a discussion of a key issue of the efficacy of advertising that evokes emotion, and how it can be a "mixed-blessing." It is suggested that the advertising strategy of South African NGOs can usefully inform NGOs in China.
\end{abstract}

Keywords: NGOs, NPOs, advertising, South Africa, China

\section{Introduction}

A modern definition of advertising can be found in The American Heritage Dictionary (2015): "The activity of attracting public attention to a product or business, as by paid announcements in the print, broadcast, or electronic media." It was also defined by Richards \& Curran (2002) as, "A paid, mediated form of communication from an identifiable source, designed to persuade the receiver to take some action, now or in the future." Advertising has been important to organizations since ancient times. It helps the seller compete with other purveyors of similar or identical products. For non-governmental organizations (NGOs), advertising is equally as important because they rely on advertising to attract outside donor funding and other outside resources such as volunteers, and government support, while enhancing social awareness.

According to Salamon \& Anheier (1992), the NGO sector includes organizations that share several common features. They are (1) formally constituted; (2) organizationally separate from the government; (3) non-profit seeking; (4) self-governing; (5) voluntary to a significant degree; and (6) non-political. Furthermore, according to Salamon et al. (1999), the NGO sector excludes religious organizations. Consequently, NGOs are neither governmental nor commercially-driven in nature, nor are they meant to serve as a substitute for state- or market-led initiatives. One can say that NGOs tend to fill the "delivery gap" that exists between government and markets. NGOs therefore supplement state- and market-led development initiatives.

NGOs tend to have consistently observed attributes which stand apart from governmental and other quasi-governmental organizations, such as: advocacy activities without governmental influence, operating on a nonprofit basis, relying on voluntary membership and participation, and are founded on the basis of a specific ideal or goal. Commonly pursued goals of many NGOs include 1) empowering the poor to become self-sufficient and self-reliant; 2) promoting civil society and development; 3) conservation and environmentalism; 3) championing human rights, and 4) other social demands that are national or international in scope. In short, NGOs are typically voluntary organizations engaged in sustainable development and poverty reduction work at local, national and global levels.

According to Prugsamatz (2010), since NGOs compete for outside resources and funding, it is especially important that NGOs engage in continuous organizational learning. Continuous learning benefits the NGO by helping its members develop better strategies, policies, actions, decisions and improved resource allocations, all of which, in turn, leads to better program implementation. The more effective the NGO is perceived to be in accomplishing its objective, the more likely it is to continue attracting the outside resources it needs to grow and develop. Also, 
learning for the sake of learning will lead to the organization's ability to grow and develop on its own and adapt efficiently to the changes around them (Bryson, 2004).

Despite the many similarities that exist among NGOs, each must adapt its strategy and method of implementation to the political, legal and macroeconomic environment of the country in which it operates. In short, NGOs from different countries have to function in accordance with their corresponding national or local environments. Since China and South Africa are both third world countries, we will compare and contrast Chinese NGOs with South African NGOs. We will note their differences, postulate why these differences exist, and provide some recommendations for Chinese NGOs that will improve the effectiveness of their advertising.

\section{NGOs in South Africa}

Non-governmental Organizations (NGOs) as we know them today, date back to the 1860's when international anti-slavery associations emerged. A country with a young and turbulent history, South Africa incubated many NGOs under the pressure of both internal and external forces. Many of these early NGOs were set up as commune-systems. Between the 1920's and 1940's, South African NGOs underwent changes in both their characteristics and significance. For instance, the Great Depression stirred up South African opposition to British colonial rule, and some South African NGOs provided the organizational basis for the country's successful independence movement. Ironically, however, after South Africa won its independence in 1931, and later still, when the National Party came to power after 1948, the very same NGOs were suppressed by the new regime to prevent further political activity, and the possibility of political upheaval. Between 1948 and 1994, apartheid reigned in South Africa. NGO's activities and funding sources were heavily restricted by the government. Up until the early 1980s, the government was only supportive of NGOs directed toward serving the white community and maintaining the racial order. In contrast, anti-apartheid NGOs were very few in number and subjected to continuous harassment until the early 1980s when the Botha regime changed the law, allowing many anti-apartheid NGOs to emerge, organize and serve the disenfranchised and marginalized black population. This newly liberalized political environment led to the proliferation of anti-apartheid NGOs which were run by professionals who were aligned with the anti-apartheid cause. The anti-apartheid NGOs further benefited from a large influx of foreign funding which was channeled directly into the NGOs. The result was a massive growth in the NGO sector to the point where, by 1990, there emerged a heavily interlocked network of about 5,000 anti-apartheid NGOs operating in South Africa. In an attempt to limit the political impact of the NGOs, the apartheid government imposed increasingly repressive censorship laws and restrictions on the NGOs, but to no avail. In 1994, the National Party's rule came to an end and along with it, apartheid rule. In effect, one can infer that from 1920-1994, NGOs in South Africa promoted freedom; first, freedom from colonial rule, and later, freedom from apartheid rule (Habib \& Taylor, 1999).

After 1994, the conflicting relationship between government and NGOs shifted away from the politics of resistance to the apartheid state to the politics of reconstruction and redistribution (Marais, 1998). Under reconstructive policies, the resources of many NGOs were absorbed or fused with the institutions of the new state and much of the funding for the NGOs was subsequently re-directed to the state. Many people trained within the NGO sector came to play important roles in government, developing policies or providing welfare and development services. Indeed, many highly-trained professionals left the NGO sector to pursue lucrative positions in government, effectively becoming "new government officials." This "brain drain" from the NGO sector compromised the organizational, managerial effectiveness of NGOs, and crippled their ability for "capacity-building." Some NGOs received more support from the government while other NGOs found it difficult to access government support. In short, funding of NGOs became caught up in the new bureaucracy. NGOs that managed to remain independent (that is, avoid fusion with the government) positioned themselves as "watchdogs" of the new state (Habib \& Taylor, 1999).

Later in 1996, the reconstructive polity of the state was replaced with a neo-liberal polity. NGOs would now be focused on growth, employment, and strategies for redistribution (referred to as GEAR). Under GEAR, emphasis was placed on private-sector investments in job creation, with state-led redistribution taking a back seat to growth and employment (Habib \& Taylor, 1999). Consequently, NGOs now sought and found partnerships and funding from businesses. Not surprisingly, these NGOs became commercialized in their orientation.

NGOs in South Africa are structured and operate under either of two models: the "top-down" or corporate model approach, established by the Dutch and English settlers through which the NGO plays an important role in delivering public welfare services to those in need; and the "bottom-up" approach where the NGO simply serves as a venue by which the individual can "pull himself up by the boot-straps" and become self-reliant and self-sufficient. 
Today, the NGOs of South Africa now are serving primarily the black population in three major areas of development: a) agriculture and poverty alleviation; b) education and training; and c) health and HIV/AIDS. In South Africa, as in most countries, NGOs must register to obtain the status of a non-profit organization (NPO) and tax exemptions. Registration as an NPO can also enable the NGO establish a unique identity. An efficiently run NGO with a unique identity would help the NGO stand apart from other NGOs and increase its prospects of attracting additional resources.

We can see the breakdown of the types of NGOs (technically, NPOs) through 2014 by referring to statistics released by South Africa in 2015; see Figure 1. Social services takes up 40.8\% in 2014 and development and housing takes up $20.4 \%$. NGO financial support comes mainly from the government and voluntary sponsors, which can be seen from Figure 2.

\begin{tabular}{|c|c|c|c|c|c|c|c|c|c|}
\hline \multirow[b]{2}{*}{ Objectives } & \multicolumn{3}{|c|}{ Types of NPI 2012} & \multicolumn{3}{|c|}{ Types of NPI 2013} & \multicolumn{3}{|c|}{ Types of NPI 2014} \\
\hline & $\begin{array}{r}\text { Voluntary } \\
\text { associations }\end{array}$ & $\begin{array}{l}\text { Non-profit } \\
\text { companies }\end{array}$ & $\begin{array}{r}\text { Non.profit } \\
\text { trusts }\end{array}$ & $\begin{array}{r}\text { Voluntary } \\
\text { associations }\end{array}$ & $\begin{array}{l}\text { Non-profit } \\
\text { companies }\end{array}$ & $\begin{array}{r}\text { Non-profit } \\
\text { trusts }\end{array}$ & $\begin{array}{r}\text { Voluntary } \\
\text { associations }\end{array}$ & $\begin{array}{l}\text { Non-proft } \\
\text { companies }\end{array}$ & $\begin{array}{r}\begin{array}{r}\text { Non-profit } \\
\text { trusts }\end{array} \\
\end{array}$ \\
\hline Culture and recreation & 5.2 & 7,1 & 6,1 & 5,1 & 7,0 & 4,7 & 5,7 & 7,7 & 6,1 \\
\hline Education & 6.9 & 14,7 & 16,9 & 7,8 & 15,2 & 18,1 & 7,1 & 11,2 & 16,0 \\
\hline Health & 10,9 & 8,6 & 6,2 & 9,7 & 7,3 & 5,9 & 9,3 & $6, ?$ & 6,0 \\
\hline Social senvices & 41.4 & 15,3 & 11,8 & 40,0 & 15,5 & 12,5 & 40,8 & 23,3 & 12,5 \\
\hline Environment & 1,1 & 3,0 & 4,0 & 1,1 & 3,1 & 4,1 & 1,1 & 2,3 & 4,1 \\
\hline Development ond housing & 19.6 & 28,5 & 15,4 & 21,6 & 28,5 & 15,6 & 20,4 & 29,5 & 18,3 \\
\hline Law, advocacy and politics & 2.0 & 3,5 & 2,2 & 2,2 & 4,1 & 2,2 & 2,2 & 3,4 & 2,6 \\
\hline $\begin{array}{l}\text { Philanthropic intermediaries and } \\
\text { voluntarism promotion }\end{array}$ & 0.4 & 3,9 & 28,2 & 0,5 & 3,9 & 28,0 & 0,4 & 2,3 & 25,5 \\
\hline International & 0,1 & 0,2 & 0,2 & 0,1 & 0,2 & 0,1 & 0,1 & $0, ?$ & 0,2 \\
\hline Religion & 11,7 & 12,8 & 8,5 & 11,5 & 13,0 & 8,2 & 12,1 & 11,4 & 8,2 \\
\hline $\begin{array}{l}\text { Business and professional } \\
\text { associations, unions }\end{array}$ & 0.5 & 2,3 & 0,5 & 0,5 & 2,2 & 0,5 & 0,8 & $2,1)$ & 0,5 \\
\hline Total & 100.0 & 100,0 & 100,0 & 100,0 & 100,0 & 100,0 & 100,0 & 100,0 & 100,0 \\
\hline
\end{tabular}

Figure 1. Types of non-profit institution by legal entity and objectives, 2012, 2013 and 2014 (\%)

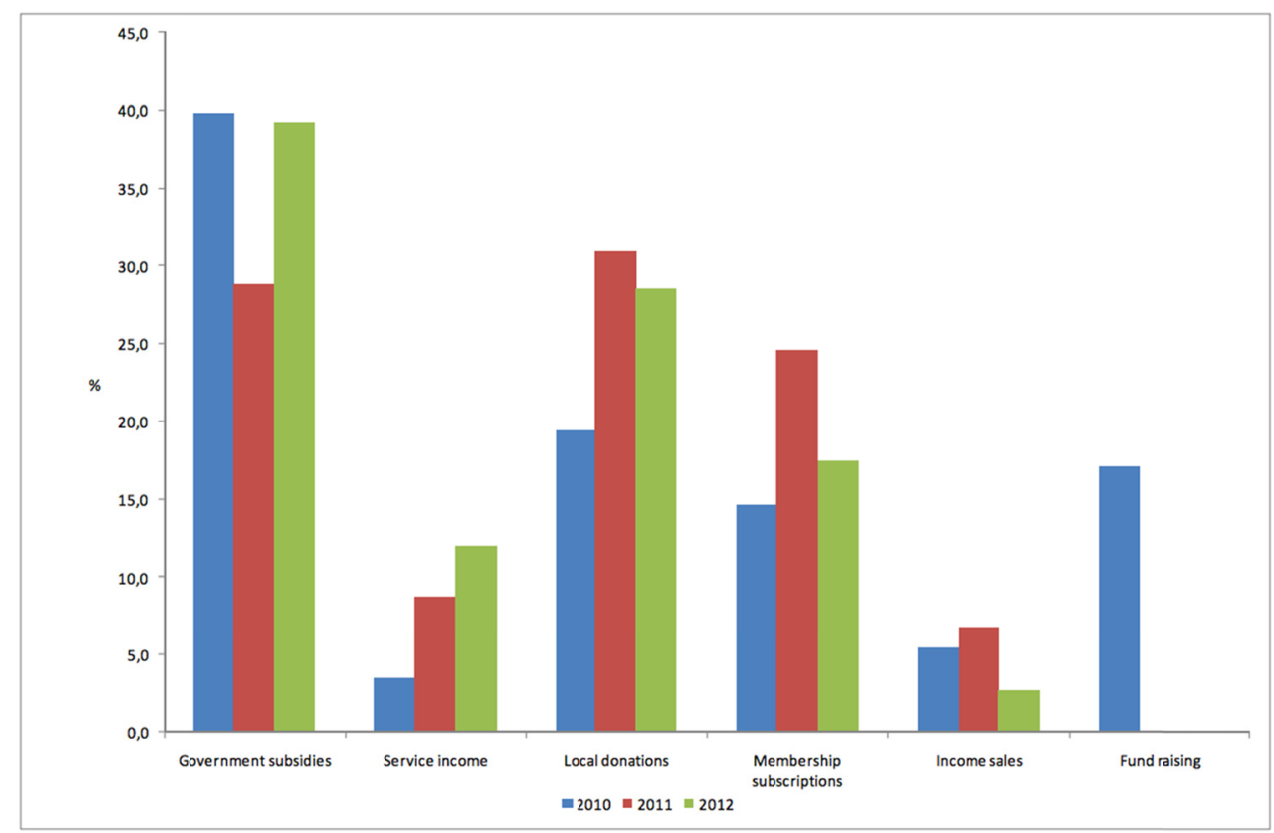

Figure 2. Income of South African non-profit institutions, 2010, 2011 and 2012, respectively 


\section{NGOs in China}

Unlike the NGOs of South Africa, the history of Chinese NGOs is short. Between 1949 and 1978, China operated under a planned economic system. The state was responsible for social welfare, so there was no need or role for NGOs to play in Chinese society. Later, NGOs were created by the Chinese government to cope with the vacuum created when the economy transitioned from totalitarianism. Market reforms and the opening up of the Chinese economy in 1978 spurred impressive economic growth, but it also created serious social problems which the government did not have the ability to deal with. The central government's policy of "small government, big society" provided space for the rapid emergence of many NGOs in China. At the same time, the Chinese communist government feared that unrestricted rapid development would unleash social forces it might not be able to control. The prospect of losing control over the economy prompted the government to legislate strict controls over the NGOs. All NGOs would be required to first find a government or party sponsor before being issued an official permit to operate (Zhang, 2005).

Legislative control over the NGOs proved to be tricky, to say the least. This is due to the existence of multiple levels of administrative and legislative authority in China. Up to five (5) sets of legal code may apply to and govern the actions of an NGO, and the different sets of rules sometimes conflict with one another. Adding to this confusion is the issue of ambiguity. Some rules were purposefully designed to be ambiguous in their interpretation and application so that local officials can use their own discretion in determining whether the NGO is legitimate or not. Operating within an environment of legal uncertainty makes it particularly challenging for Chinese NGOs to develop and maintain a clear strategic vision or an effective program implementation. NGOs that are legally difficult to manage do not tend to attract or retain professional leadership. Without effective leadership, NGOs are less likely to receive government support and funding.

Unlike NGOs in South Africa, NGOs in China underwent an overall "rectification activity" under the implementation of the Association Registration and Management Regulations in 1998. This led to a decline in the number of NGOs in China. By the end of 1998, the number of NGOs dropped from 200,000 to 165,000. However, according to data from the Economist (2014), the number of China's NGOs has increased after 1998 (see Figure 3).

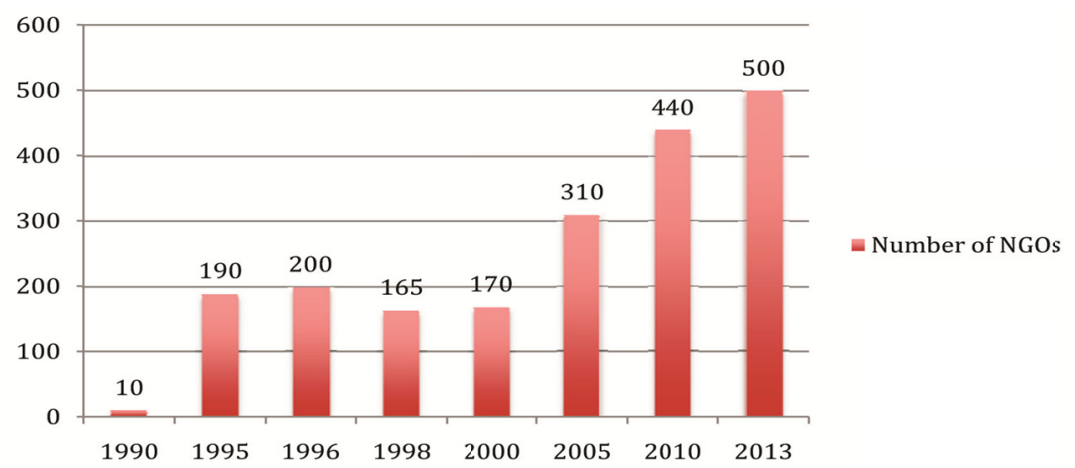

Figure 3. Number of NGOs registered in China (000)

Chinese NGOs are chiefly concerned with education, improved sanitation in rural and urban areas, poverty alleviation, and the delivery of social services to vulnerable groups (e.g., migrant workers, children, women, etc.) Nevertheless, due to the communist political structure in China, NGOs face many difficulties, including insufficient funding, unprofessional management, inappropriate commercialized operations, and the lack of independence, policy support, legal support, and social support. Additionally, NGOs in China have little ability to obtain publicity. To add to the aforementioned woes of the NGOs, an article appeared in a recent publication discussing the "death of Chinese NGOs." The article delivered a negative prognosis for the NGOs' ability to survive, stand on their own merits or build capacity in a sustainable manner (Amagoh, 2015).

When we compare South African NGOs to Chinese NGOs, we may infer that NGOs play a more important role in South Africa than in China. South African NGOs are more developed, mature, and have strong legal standing with rights that are secure. Chinese NGOs are in a weaker position due to being under the control of the central and local governments while simultaneously being left without support from the same government that controls them. 


\section{NGOs Advertising in South Africa vs. NGOs Advertising in China}

Advertising is a very important activity for modern NGOs. However, NGOs will usually have a smaller budget than business organizations. The primary goal of NGO advertising is to raise funds. However, there are three additional goals of advertising, namely:

- Attract society's attention on an issue and educate society about the issue.

- Enhance citizens' awareness and promote upcoming activities for the purpose of increasing the population of supporters.

- Inform the population about the outcomes of the organization's effort.

In terms of advertising approach, we can see that both China's and South Africa's NGOs typically use an emotional approach. This is, perhaps, true for all countries. There often seems to be a moving story and/or a set of emotional-engendering photographs in their promotion campaign. "Through the medium of the photograph, the viewer is drawn into the position of being witness to the portrayed distant events. In this way, suffering becomes real to those who are elsewhere." (Kennedy \& Kapyla, 2010) As stated by Papp-Váry (2015), "most people are emotional, although they tend to look for a rational explanation of their purchase decision." It is said that an emotional approach can trigger passion in an audience, which will create a lasting impact on them.

South Africa's advertising is relatively straightforward and utilizes visual effects in their marketing campaigns. On occasion, shock tactics are used successfully to grab the audience's attention (Rideout, 2011). Additionally, South African NGOs utilize foreign support. Consider an NGO named the Kliptown Youth Program (KYP), in Soweto, whose focus is to help children and youth in local communities learn basic social knowledge and develop themselves in a well-rounded way. They offer tutorial classes in arts, resumé development, athletics and offer free food as an incentive to attend.

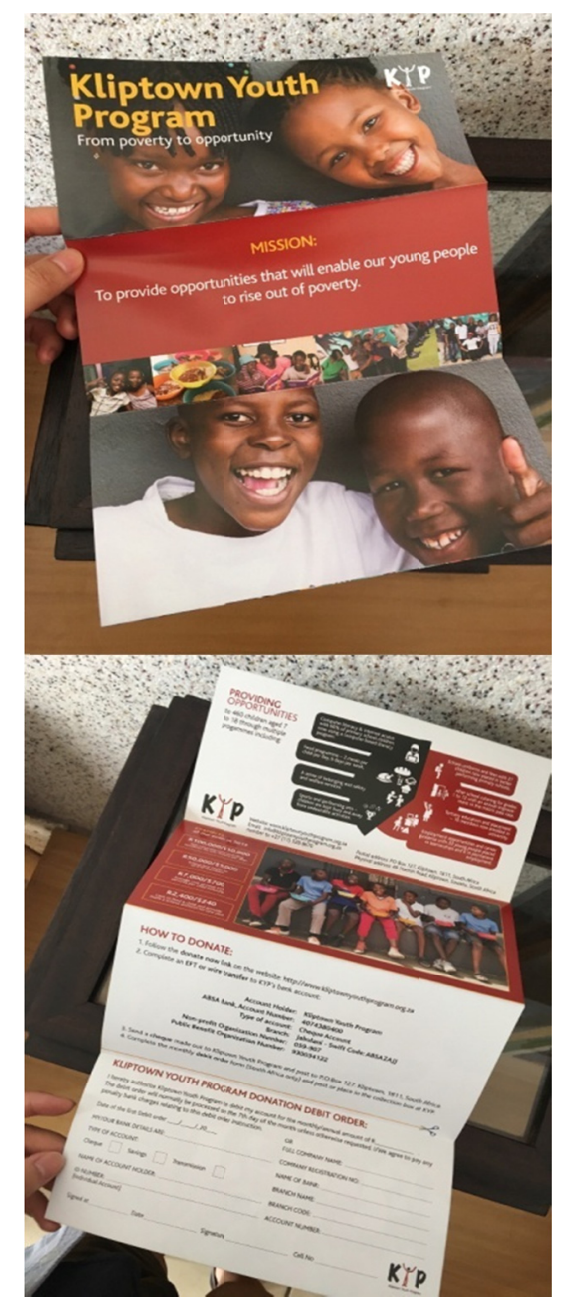

Figure 4. Flyers of KYP 
Helpers from overseas countries visit Soweto annually to contribute their services. In 2015, KYP had several students from the University of Pennsylvania visit and assist while also receiving course credit. This group of students helped KYP design promotional flyers (see Figure 4), and develop an official KYP website (see Figure 5).
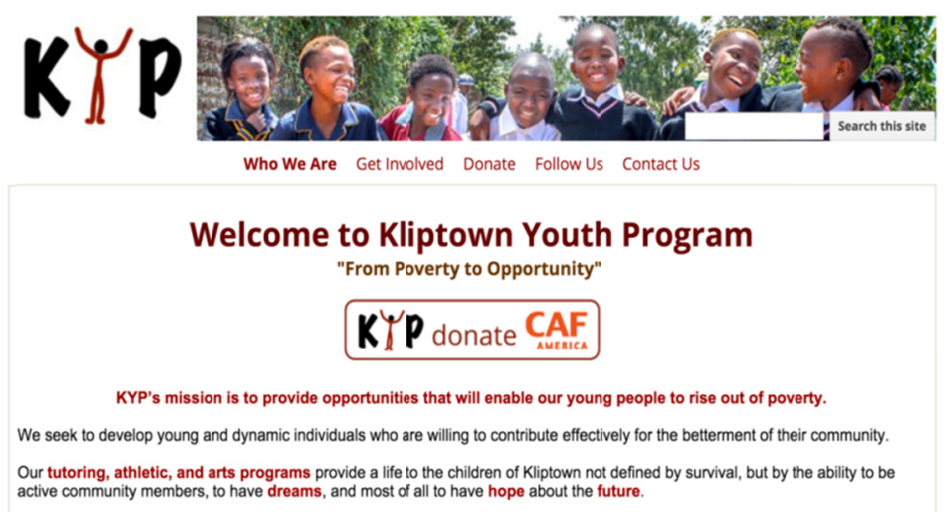

Figure 5. KYP official website

Compared to South African NGOs, Chinese NGOs are imbued with strong political characteristics. Consider the All-China Women's Federation as an example; its official website is populated with the latest political events in China, the 12th National People's Congress (see Figure 6).

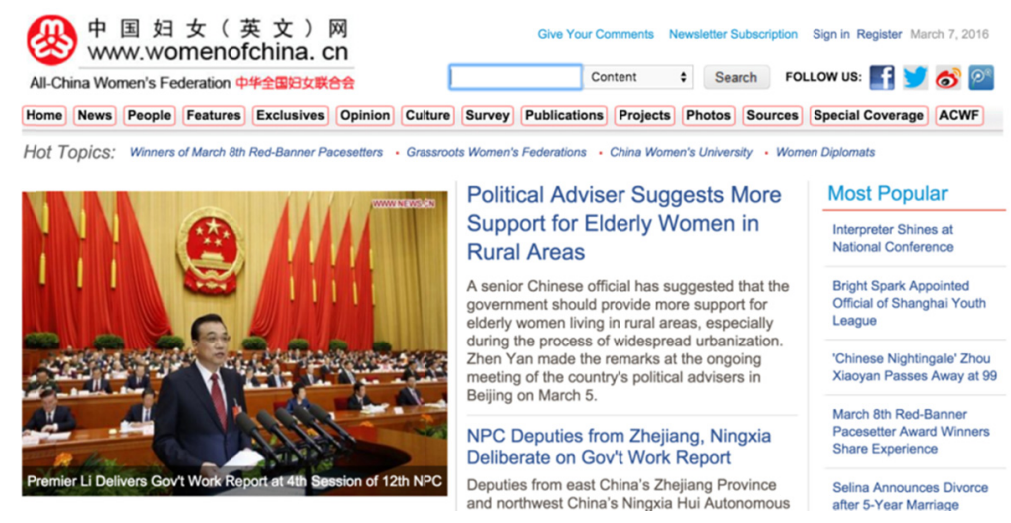

Figure 6. Homepage of the All-China Women's Federation

Generally, we can see that South African NGOs' advertising is more freestyle than that of Chinese NGOs. And yet, with South African NGOs there remain lingering memories and resentment of apartheid. For example, the "Hungry Child" ad (see Figure 7), which features a white person feeding a "tidbit" to a black child, sparked a racial storm when it was released. This ad failed to appeal to the targeted audience for obvious reasons. It didn't help that the child seemed to be seated in a position similar to a dog when it is begging for table scraps.

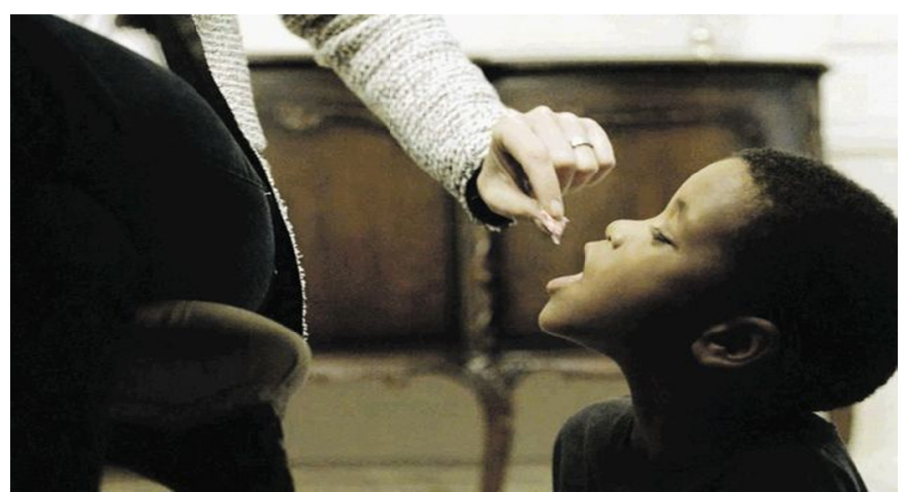

Figure 7. The Hungry child advertisement 
The advertisement was labeled as "hugely racist" and "in poor taste" by YouTube. The advertising agency, Ogilvy and Mather, Cape Town, received lots of complaints and negative publicity over the ad, and several people claimed that the ad even promoted pedophilia. Not surprisingly, the Hungary Child SA advertisement was quickly removed from YouTube.

\section{Recommendations for China's NGO Advertising}

\subsection{Enhance Visibility While Paying Attention to Social Equality}

Based on NGO research in general, and specifically in South Africa, it is clear that NGO advertising in China lacks visibility. Instead of using textual promotions, images and short videos should be used to catch the eyes of the audience in a more engaging manner. "Today, you have to search for visibility," noted Sana Das, Amnesty International's then-coordinator for growth, membership and activism (Granito, 2007). She continues, "The whole world has turned into a series of images. If you aren't represented in that world, it's possible that people might just pass you by. Even though you might be saying some of the most important things that can be said, no one might hear them." However, advertisers should exercise caution and sensitivity to avoid creating the perception of discrimination when developing and launching a campaign. Otherwise, the campaign may backfire on the NGO, as in the aforementioned Hungry Child ad.

\subsection{Invest more on Publicity and Building a Good Brand Image}

Chinese NGOs are lacking publicity, as most people are not aware of what they are doing. The organizations should invest more in marketing themselves to the public. Today, NGOs are encouraged to fully utilize the advantages of social media through digital marketing.

Furthermore, the development and maintenance of a positive brand image is vital to the NGO. Managing an NGO is like managing a company. Customers will come to you only if you have created a positive brand image. However, given the social situation in China, an increasing number of NGOs are evolving into commercialized organizations out of necessity due to lack of financial resources and an inability to obtain money without engaging in commercial activities. However, there is a potential risk to the use of commercial activities - namely, it can turn off potential donors. A "fine line" must be walked as the NGO engages in commercial activities while also appealing to donors.

Rumors can affect the reputation of an organization. For instance, the Red Cross of China was rumored to be using donations improperly. When the rumor reached the public, and worse still, was later confirmed as fact, donations plummeted dramatically! Hence, building and maintaining a positive brand image is crucial to the NGO. Managers and staff must be especially sensitive to this issue.

\subsection{Enhance Creativity}

Usually, NGO advertisements are filled with gloom and sadness. However, there are other ways of appealing to audiences. Instead of featuring crying scenes, advertisers can think about bringing optimistic scenes to the customers, such as positioning NGOs as organizations that bring people love and hope. In contrast to sad advertisements, audiences may be more receptive to positive promotional campaigns.

NGOs need to consider the literature in the area of "message framing" to take advantage of what will likely work best for them. There have been studies that compare positive vs. negative valence in messages and compare donation rates and donation amounts. For example, which will do better? An advertisement which communicates, "Without your generous donation, deserving children will not have the opportunity to $X Y Z$,"- - negative valence, or, "With your generous donation, deserving children will have the opportunity to $X Y Z$ "-positive valence (e.g., Smith \& Berger, 1998; Berger \& Smith, 1998).

According to a research done by Reinartz \& Saffert (2013), a euro invested in a highly creative ad campaign had, on average, nearly double the sales impact of a euro spent on a noncreative campaign. In order to be effective, an NGO should have a team that can develop creative concepts for an impactful advertising campaign. Such a team might include a copywriter, designer, director, and an account planner (Hefer, 2010). Creativity should build a unique brand image, which will make the NGO more recognizable to the public.

Below is a print advertisement from Cordaid (see Figure 8). This series of ads seeks to build social awareness about poverty in Africa. By stating the price of luxury products and the price of food and water, the ad may evoke feelings of guilt and charity for the poor who barely survive at the bottom rung of society. The strong comparison between the luxury accessories and basic foodstuffs has the effect of delivering an emotional shock to the audience. Those who have a Hermes tote bag on their arm might be triggered to donate money to the organization. Likewise, Chinese NGOs should consider mimicking successful print campaigns designed to serve 
a Chinese audience.
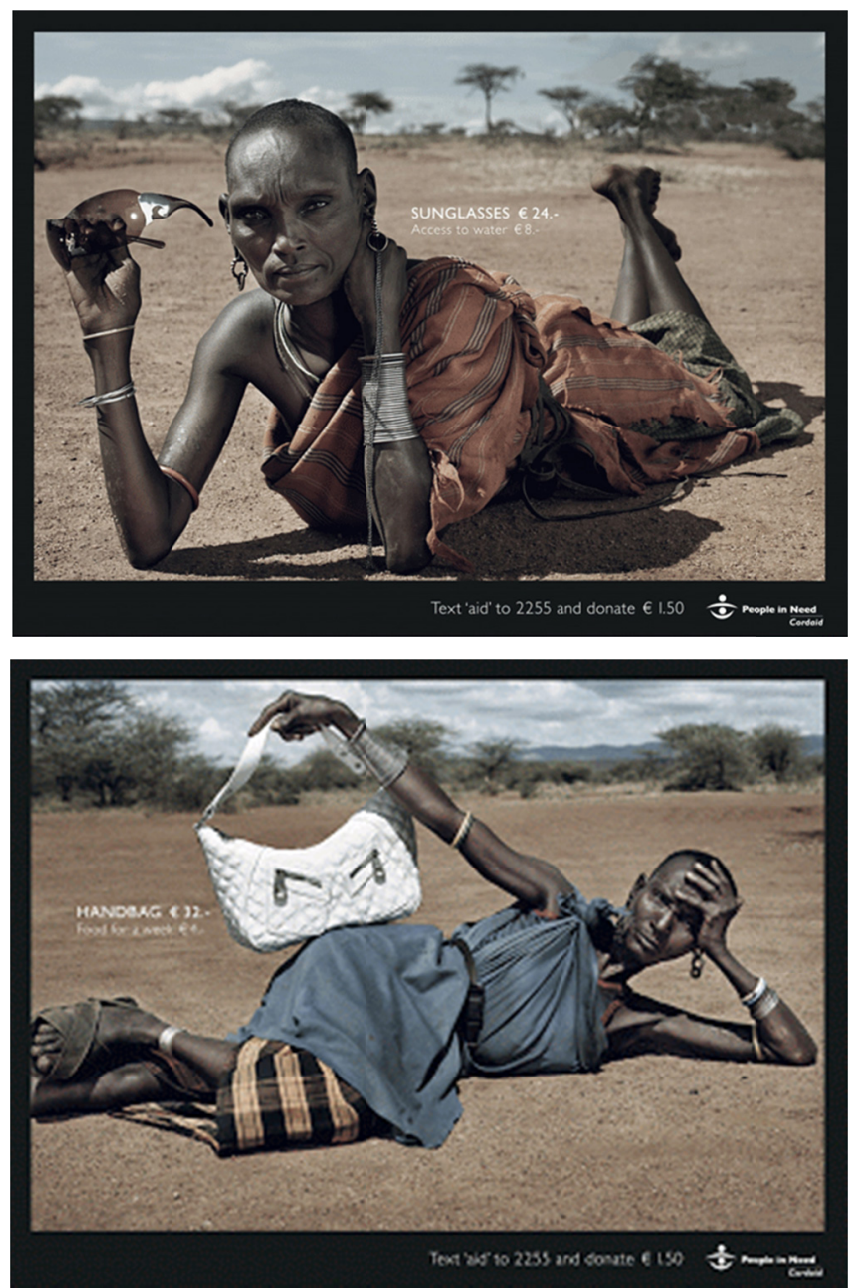

Figure 8. A South African print ad campaign example

\subsection{Learn to Utilize Foreign Support}

In China, receiving budget support from the central government is a very complicated process, due to the political structure of the country. As the central government restricts the development of NGOs in China, the contributions to NGOs by the government are very limited. Hence, NGOs in China will need to think about other ways to obtain financing, such as 1) build a network with a supporting structure that accepts foreign financial aid and volunteers (as in the case of South Africa by KYP), 2) interacting with international schools and corporations, and 3 ) cooperating with other large international NGOs. Through such efforts, Chinese NGOs may be able to attract more funding and benefit from the reputation and successful endeavors such organizations. In fact, Chinese NGOs can even arrange a direct partnership with South African NGOs oriented toward sharing management expertise and experience, and, perhaps, more outreaching facilities.

\section{Conclusions}

In conclusion, South Africa has a more mature NGO structure and more sophisticated advertising process compared to that of China. Chinese NGOs can learn from the South African NGO experience, and adapt several principles to the Chinese environment. South African NGOs are, in the majority, doing well, and are using effective advertising, but, even so, need to pay attention to potential racial issues when launching an advertising campaign.

\section{Limitations of the study}

Although both South Africa and China are the third world countries, there exist notable differences between them, which bring some limitations to this research. First of all, there are cultural, political and legal differences 
between the two countries. Second, there are differences in the two countries' struggle for independence from colonialism. Third, there are economic differences and differences in the international status of these two countries, which in turn affects the international community's treatment of Chinese vs. South African NGOs.

\section{References}

Amagoh, F. (2015). Improving The Credibility And Effectiveness Of Non-Governmental Organizations. Progress in Development Studies, 15(3), 221-239. Business Source Complete. https://doi.org/10.1177/1464993415578979

American Heritage Dictionary. (2015). 5th Edition. Boston: Houghton Mifflin.

Berger, P. D., \& Gerald, S. (1998). The Impact of Prospect Theory Based Framing Tactics on Advertising Effectiveness. OMEGA: The International Journal of Management Science, 26(5), 593-609. https://doi.org/10.1016/S0305-0483(98)00009-7

Bryson, J. (2004). Creating and Implementing your Strategic Plan: A Workbook for Public and Non-Profit Organizations (2nd ed.). San Francisco, CA: Jossey-Bass.

Enter the Chinese NGO-The Communist Party Is Giving More Freedom to a Revolutionary Idea. (2014). The Economist.

Final Statistics of the Non-profit Sector for South Africa. (2015). Statistics South Africa.

Granito, A. (2007). GO Advertising: Visibility Counts. Livemint, 30.

Habib, A., \& Taylor, R. (1999). South Africa: Anti-Apartheid NGOs in Transition. International Journal of Voluntary and Nonprofit Organizations, 10(1), 73-82. https://doi.org/10.1023/A:1021495821397

Hefer, D. (2010). From Witblits to Vuvuzelas: Marketing in the New South Africa (Chapter 5, pp. 1684-1954). South Africa: Zebra Press.

Kennedy, D., \& Juha, K. (2010). Emotions, Rationality, and International Relations: Narratives in NGO Advertising Campaigns. Conference Papers-International Studies Association.

Marais, H. (1998). South Africa, Limits to Change: The Political Economy of Transformation. Zed, London.

Papp-Váry, Á. (2015). What Makes Good Advertising? 12 Timeless Principles Based On The Advice Of Famous Advertising Gurus. Journal of Media Research, 8(3), 35-56.

Prugsamatz, R. (2010). Factors that influence organization learning sustainability in non-profit organizations. The Learning Organization, 17(3), 243-267. https://doi.org/10.1108/09696471011034937

Reinartz, W., \& Saffert, P. (2013). Creativity in Advertising: When It Works and When It Doesn't. Harvard Business Review, 38, 110-120.

Richards, J., \& Catharine, C. (2002). Oracles On Advertising: Searching For A Definition. Journal Of Advertising, 31(2), 63-77. https://doi.org/10.1080/00913367.2002.10673667

Rideout, L. (2011). Representations Of The Third World' In NGO Advertising: Practicalities, Colonial Discourse And Western Understandings Of Development. Journal of African Media Studies, 3(1), 25-41. https://doi.org/10.1386/jams.3.1.25_1

Salamon, L., \& Helmut, A. (1992). In Search of the Non-Profit Sector I: The Question of Definition. Voluntas: International Journal of Non-Profit Organizations, 3(2), 125-151. https://doi.org/10.1007/BF01397770

Salamon, L., Anheier, H., List, R., Toepler, S., \& Wojciech, S. S. (1999). Global Civil Society Dimensions of the Nonprofit Sector. John Hopkins Center for Civil Society.

Smith, G., \& Berger, P. D. (1998). Different Message-Framing For Different Direct Response Marketing Goals. $\begin{array}{lllll}\text { Journal of } & \text { Interactive } & \text { Marketing, } & \text { 32(2), }\end{array}$ https://doi.org/10.1002/(SICI)1520-6653(199821)12:2\%3C33::AID-DIR4\%3E3.0.CO;2-Z

Zhang, J. X. (2005). A Comparative Study of NGOs in China and South Africa. Unpublished Dissertation, University of the Western Cape.

\section{Copyrights}

Copyright for this article is retained by the author, with first publication rights granted to the journal.

This is an open-access article distributed under the terms and conditions of the Creative Commons Attribution license (http://creativecommons.org/licenses/by/4.0/). 